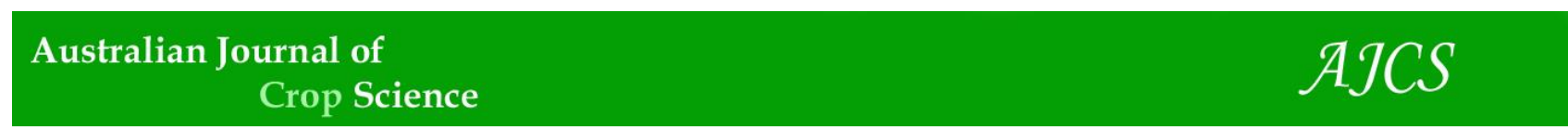

AJCS 12(10):1578- 1586 (2018)

ISSN:1835-2707

doi: 10.21475/ajcs.18.12.10.p1120

\title{
Exogenous proline affects nitrogen assimilation, mineral uptake, and antioxidant activity in tomato plants under $\mathrm{NO}_{3}{ }^{-} / \mathrm{NH}_{4}{ }^{+}$proportions
}

\author{
Roberta Corrêa Nogueirol ${ }^{1 *}$, Simone da Costa Mello ${ }^{1}$, João Cardoso de Souza Junior ${ }^{2}$, Durval Dourado \\ Neto ${ }^{1}$ and Francisco Antonio Monteiro ${ }^{2}$
}

${ }^{1}$ Crop Science Department, University of São Paulo (ESALQ/USP) Piracicaba, SP, Brazil, 13418-900

${ }^{2}$ Soil Science Department, University of São Paulo (ESALQ/USP) Piracicaba, SP, Brazil, 13418-900

*Corresponding author: robertanogueirol@gmail.com

\begin{abstract}
The nitrate $\left(\mathrm{NO}_{3}{ }^{-}\right)$reduction process is complex and has a high energy cost for plants when $\mathrm{N}$ is provided exclusively as $\mathrm{NO}_{3}{ }^{-}$. For this reason, the addition of part of $\mathrm{N}$ in the form of ammonium $\left(\mathrm{NH}_{4}{ }^{+}\right)$may improve the development of many species. There are no studies showing how proline spray may affect plants under $\mathrm{NH}_{4}{ }^{+} / \mathrm{NO}_{3}{ }^{-}$treatment in varying proportions. The objective was to evaluate the role of exogenously applied proline on $\mathrm{N}$ assimilation, photosynthesis, chlorophyll content, antioxidant activity, mineral uptake, and biomass production of tomato plants in initial growth treated with $\mathrm{NO}_{3}^{-} / \mathrm{NH}_{4}^{+}$in varying proportions. The experiment was carried out with $\mathrm{NO}_{3}{ }^{-} / \mathrm{NH}_{4}^{+}$proportions $(100 / 0,70 / 30$ e 50/50) and exogenous proline doses rate $(0,10$ e $20 \mathrm{mmol}$ $\left.\mathrm{L}^{-1}\right)$. The parameters of production, nutrition and enzyme activity of the antioxidant system of tomato plants were evaluated. The $\mathrm{NO}_{3}^{-} / \mathrm{NH}_{4}^{+}$proportions and proline spray did not affect the plant biomass, but the SPAD value, $\mathrm{CO}_{2}$ assimilation, and stomatal conductance were lower in plants supplied with $\mathrm{NO}_{3}{ }^{-}$exclusively. Proline concentration in the shoots was increased with the proline rate applied exogenously. The nitrate reductase activity was enhanced by proline rates only in plants under $\mathrm{NO}_{3}^{-}$ exclusively, whereas glutamine synthase was not affected by proline spray. However, proline spray decreased $\mathrm{NH}_{4}{ }^{+}$concentration in shoots of the plants grown under $100 / 0$ and $70 / 30 \mathrm{NO}_{3}{ }^{-} / \mathrm{NH}_{4}{ }^{+}$, but not in the roots. The $\mathrm{NO}_{3}{ }^{-}$concentration and accumulation in roots were raised by proline spray only in plants grown under $\mathrm{NO}_{3}{ }^{-}$exclusively, indicating that proline is an excellent osmoregulator, which explains the maintenance of $\mathrm{NO}_{3}{ }^{-}$in the roots. Proline spray increased $\mathrm{N}$ assimilation and mineral uptake. Ascorbate peroxidase, catalase, and guaiacol peroxidase activity in shoots was higher in plants treated with a proline rate of 20 $\mathrm{mmol} \mathrm{L}$. Producers using proline spray for tomato plants should consider the $\mathrm{NO}_{3}{ }^{-} / \mathrm{NH}_{4}^{+}$proportions, because the proline supply affects $\mathrm{NO}_{3}{ }^{-}$and $\mathrm{NH}_{4}{ }^{+}$uptake, nitrate reductase activity, and antioxidant activity in tomato plants under treatment from $\mathrm{N}$ ionic forms.
\end{abstract}

Keywords: Solanum lycopersicum; photosynthesis; SPAD; N forms; foliar application.

Abbreviations: $A_{-} \mathrm{CO}_{2}$ assimilation rate; APX_ascorbate peroxidase; CAT_catalase; FW_fresh weight; GPOX_guaiacol peroxidase; GR_glutathione reductase; GS_glutamine synthetase; $\mathrm{N} \_$nitrogen; $\mathrm{NH}_{4}{ }_{-}^{-}$ammonium; $\mathrm{NO}_{3}^{-}$_nitrate; NR_nitrate reductase; SC_stomatal conductance; SOD_superoxide dismutase.

\section{Introduction}

Nitrogen (N) is the most important nutrient in crop yield (Piwpuan et al., 2013). Therefore, agricultural producers are greatly concerned about improving the efficiency of the use of this element. The production of $\mathrm{N}$ fertilizer has a highenergy demand and the leaching of $\mathrm{N}$ into the environment has negative impacts on the surrounding ecosystem ( $\mathrm{Xu}$ et al., 2012). In developed countries, the use of high amounts of $\mathrm{N}$ fertilizer can help to prevent fluctuations in the soil $\mathrm{N}$ availability and thus ensures consistently high crop productivity. However, in developing countries, most crop producers rarely employ a large amount of $\mathrm{N}$ fertilizers per unit area, which indicates the need for studies addressing the use of fertilizers and strategies for increasing $\mathrm{N}$ use efficiency (Kant et al., 2011).

Higher plants have the ability to uptake nitrogen $(\mathrm{N})$ as ammonium $\left(\mathrm{NH}_{4}{ }^{+}\right)$, nitrate $\left(\mathrm{NO}_{3}{ }^{-}\right)$, and other water-soluble organic compounds such as amino acids (Luo et al., 2013). Within the literature, environmental factors have been shown to influence the uptake of $\mathrm{N}$ in plants; e.g., light intensity altering the $\mathrm{NO}_{3}{ }^{-}$uptake (Ma et al., 2016a, 2016b), and tropical plants benefitting from the supply of large amounts of $\mathrm{NO}_{3}{ }^{-}$, whilst species grown in cold climates displaying a preference for the uptake of organic $\mathrm{N}_{\text {and }} \mathrm{NH}_{4}{ }^{+}$ (Boczulak et al., 2014). Despite this, $\mathrm{NO}_{3}{ }^{-}$is generally considered the preferential ionic form of $\mathrm{N}$ uptake (Britto and Kronzucker, 2013).

Reports by Konnerup and Brix (2010), and Degiovanni et al. (2010) show that plants supplied with a solution of both $\mathrm{NO}_{3}{ }^{-}$and $\mathrm{NH}_{4}{ }^{+}$have better growth and development than plants fertilized separately with these nutrients. However, these authors suggest that the percentage of $\mathrm{NH}_{4}{ }^{+}$should be equal or lower than $50 \%$, since excess $\mathrm{NH}_{4}{ }^{+}$can be toxic to 
plants (Chen et al., 2013). This is due to $\mathrm{NH}_{4}^{+}$toxicity dissipating the transmembrane gradient protons in the cell, the main source of energy for the ATP synthesis (Marschner, 2012).

Proline is a molecule directly involved in the plants defense to various types of adverse environmental conditions (Cvikrová et al., 2012). This multi-functional amino acid, stabilizes sub cell structures such as proteins, enzymes, and cell membranes, thereby eliminating reactive oxygen species, ensuring cell homeostasis, signaling events, and buffering the redox potential (Hayat et al., 2012). In the $N$ assimilation pathway, the first three amino acids generated are glutamate, proline, and asparagine (Marschner, 2012). Therefore, exogenous proline application on tomato leaves may be a way to provide this readily available amino acid without the need for metabolic energy expenditure, which may improve the $\mathrm{N}$ assimilation efficiency, antioxidant activity and photosynthesis; thus, increasing plant growth. Despite this, there are no studies showing the ideal proportions of $\mathrm{NO}_{3}{ }^{-} / \mathrm{NH}_{4}{ }^{+}$fertilization for plants under exogenous proline application.

There is also a lack of studies showing the interaction between $\mathrm{NH}_{4}^{+}$and its assimilation products, such as the amino acid: proline. The interaction could be important for the activation of $\mathrm{N}$ assimilation in metabolic pathway, antioxidant system improvement and photosynthesis (Misra and Gupta, 2006; Hessini et al., 2009). Therefore, the hypothesis of the current study is that exogenous proline may interact with $\mathrm{NO}_{3}{ }^{-} / \mathrm{NH}_{4}{ }^{+}$to increase $\mathrm{N}$ assimilation and thus mineral uptake, photosynthesis, and plant growth. The objective of this study was to evaluate the influence of proline applied exogenously in relation to $\mathrm{N}$ assimilation, photosynthesis, chlorophyll content (SPAD), antioxidant activity, mineral uptake, and biomass production of tomato plants in initial growth under $\mathrm{NO}_{3}{ }^{-} / \mathrm{NH}_{4}{ }^{+}$proportions.

\section{Results}

\section{Visual changes caused by the treatments}

Plants grown under the $50 / 50 \mathrm{NO}_{3}{ }^{-} / \mathrm{NH}_{4}{ }^{+}$nutrient solution showed a darker green color in comparison to plants grown with $\mathrm{N}$ supplied with $\mathrm{NO}_{3}{ }^{-}$exclusively. The roots were shorter and more branched in plants grown with solutions with higher proportions of $\mathrm{NH}_{4}^{+}$.

\section{Biomass production and plant nutrition}

While the biomass of shoots and roots was not affected by $\mathrm{NO}_{3}{ }^{-} / \mathrm{NH}_{4}{ }^{+}$proportions and proline rates (Table 1 ), mineral concentration and accumulation were affected by treatments. Plants grown with the $50 / 50 \mathrm{NO}_{3}{ }^{-} / \mathrm{NH}_{4}{ }^{+}$had the highest $\mathrm{NH}_{4}^{+}$concentrations within each proline rate group (Figure 1). Proline spray rates of 10 and $20 \mathrm{mmol} \mathrm{L}^{-1}$ did not affect the $\mathrm{NH}_{4}^{+}$concentration in the shoots of plants grown with $50 / 50 \mathrm{NO}_{3}{ }^{-} / \mathrm{NH}_{4}{ }^{+}$, but plants treated with these proline rates plus $100 / 0$ or $70 / 30 \mathrm{NO}_{3}{ }^{-} / \mathrm{NH}_{4}{ }^{+}$showed decreases in $\mathrm{NH}_{4}{ }^{+}$concentrations in the shoots (Figure 1a). Plant roots treated with proline spray showed increases in $\mathrm{NH}_{4}^{+}$ concentration when plants were grown with $50 / 50 \mathrm{NO}_{3}^{-}$ $/ \mathrm{NH}_{4}{ }^{+}$(Figure $1 \mathrm{~b}$ ). Ammonium accumulation in the shoots was greater in the plants supplied with $50 / 50 \mathrm{NO}_{3}{ }^{-} / \mathrm{NH}_{4}{ }^{+}$and proline $20 \mathrm{mmol} \mathrm{L}^{-1}$ respectively, when compared to other
$\mathrm{NO}_{3}{ }^{-} / \mathrm{NH}_{4}{ }^{+}$proportions or proline rates (Table 1 ). In the roots, higher $\mathrm{NH}_{4}^{+}$accumulation was found in plants grown under $70 / 30$ and $50 / 50 \mathrm{NO}_{3}{ }^{-} / \mathrm{NH}_{4}{ }^{+}$when compared with those supplied with $\mathrm{N}$ solely in the form of $\mathrm{NO}_{3}{ }^{-}$(Table 1).

Highest $\mathrm{NO}_{3}^{-}$concentration and accumulation in the tomato shoots were found in plants treated with $\mathrm{N}$ solely in the form of $\mathrm{NO}_{3}{ }^{-}$(Table 1 ). In the roots, results showed that the proline spray of 10 and $20 \mathrm{mmol} \mathrm{L}^{-1}$ led to higher $\mathrm{NO}_{3}^{-}$ concentrations (Figure 1c), and accumulations (Figure 1d) in the plants supplied with $\mathrm{N}$ solely in the form of $\mathrm{NO}_{3}{ }^{-}$. Proline did not affect $\mathrm{NO}_{3}{ }^{-}$concentration and accumulation in roots of plants under $\mathrm{N}$ in the form of $\mathrm{NO}_{3}{ }^{-}$(Figure 1c, 1d)

Plants grown under $70 / 30$ and $50 / 50 \mathrm{NO}_{3}{ }^{-} / \mathrm{NH}_{4}{ }^{+}$showed higher total $\mathrm{N}$ concentrations in the shoots than in plants receiving $100 / 0 \mathrm{NO}_{3}{ }^{-} / \mathrm{NH}_{4}{ }^{+}$(Table 1 ). In the roots, proline spray resulted in lower total $\mathrm{N}$ concentrations in the plants cultivated with $70 / 30 \quad \mathrm{NO}_{3}{ }^{-} / \mathrm{NH}_{4}{ }^{+}$(Figure 1e). Total $\mathrm{N}$ accumulation in tomato roots was highest in plants grown under $50 / 50 \mathrm{NO}_{3}{ }^{-} / \mathrm{NH}_{4}{ }^{+}$treatment (Table 1 ).

\section{Nitrogen metabolism enzymes activity}

The NR enzyme activity was increased by proline rates only when the plants were grown with $\mathrm{N}$ exclusively in the form of $\mathrm{NO}_{3}{ }^{-}$(Figure 2a). With proline treatment rates of 10 and $20 \mathrm{mmol} \mathrm{L}{ }^{-1}$, NR activity was lowest at the $50 / 50 \mathrm{NO}_{3}{ }^{-} / \mathrm{NH}_{4}{ }^{+}$. The GS enzyme activity was highest in plants grown under $100 / 0 \mathrm{NO}_{3}{ }^{-} / \mathrm{NH}_{4}{ }^{+}$treatment (Figure $2 \mathrm{~b}$ ).

\section{Antioxidant system and photosynthetic activity of plants}

The supply of proline via leaf spraying increased the proline concentration in the tomato shoots, and values observed in the sprayed plants were higher than in non-sprayed plants (Table 2). The supply of $\mathrm{NO}_{3}{ }^{-} / \mathrm{NH}_{4}{ }^{+}$proportions changed the proline concentration in the roots, with lower values observed as the concentration of $\mathrm{NH}_{4}{ }^{+}$in the nutrient solution was increased (Table 2).

The GR enzyme activity presented highest values in plants receiving $\mathrm{NO}_{3}{ }^{-}$and $\mathrm{NH}_{4}{ }^{+}$when compared with those treated with $\mathrm{N}$ as $\mathrm{NO}_{3}{ }^{-}$exclusively (Table 2 ). In the roots, the lowest GR activity was found in the plants grown under $50 / 50 \mathrm{NO}_{3}{ }^{-}$ $/ \mathrm{NH}_{4}{ }^{+}$and in those receiving foliar application of proline 20 mmol $\mathrm{L}^{-1}$ in comparison with the other $\mathrm{NO}_{3}{ }^{-} / \mathrm{NH}_{4}^{+}$ proportions or rates of proline, respectively (Table 2).

The supply of $50 / 50 \mathrm{NO}_{3}{ }^{-} / \mathrm{NH}_{4}{ }^{+}$resulted in lower CAT enzyme activity when compared with the other proportions (Table 2). However, plants supplied with proline $20 \mathrm{mmol} \mathrm{L}^{-1}$ showed higher CAT and GPOX activity than plants not treated with proline spray (Table 2). In the roots, GPOX activity was lower at the $50 / 50 \mathrm{NO}_{3}{ }^{-} / \mathrm{NH}_{4}{ }^{+}$than in $100 / 0$ $\mathrm{NO}_{3}{ }^{-} / \mathrm{NH}_{4}{ }^{+}$(Table 2).

The net photosynthesis and stomatal conductance was higher in plants grown under 70/30 and 50/50 $\mathrm{NO}_{3}{ }^{-} / \mathrm{NH}_{4}{ }^{+}$ proportions than in plants under $\mathrm{N}$ as $\mathrm{NO}_{3}{ }^{-}$exclusively (Table 2). Similarly, the SPAD value increased as the $\mathrm{NH}_{4}^{+}$ proportion in the $\mathrm{NO}_{3}{ }^{-} / \mathrm{NH}_{4}^{+}$solution was increased (Table 2). However, proline spray did not affect photosynthesis or the SPAD values.

Proline $20 \mathrm{mmol} \mathrm{L}^{-1}$ via leaf spraying resulted in highest APX enzyme activity (Figure 3a). 
Table 1. Concentration and accumulation of $\mathrm{NO}_{3}{ }^{-}, \mathrm{NH}_{4}{ }^{+}$, and total $\mathrm{N}$ in the shoots and roots of tomato plants under $\mathrm{NO}_{3}{ }^{-} / \mathrm{NH}_{4}{ }^{+}$ proportions in nutrient solution and proline spray ${ }^{1}$.

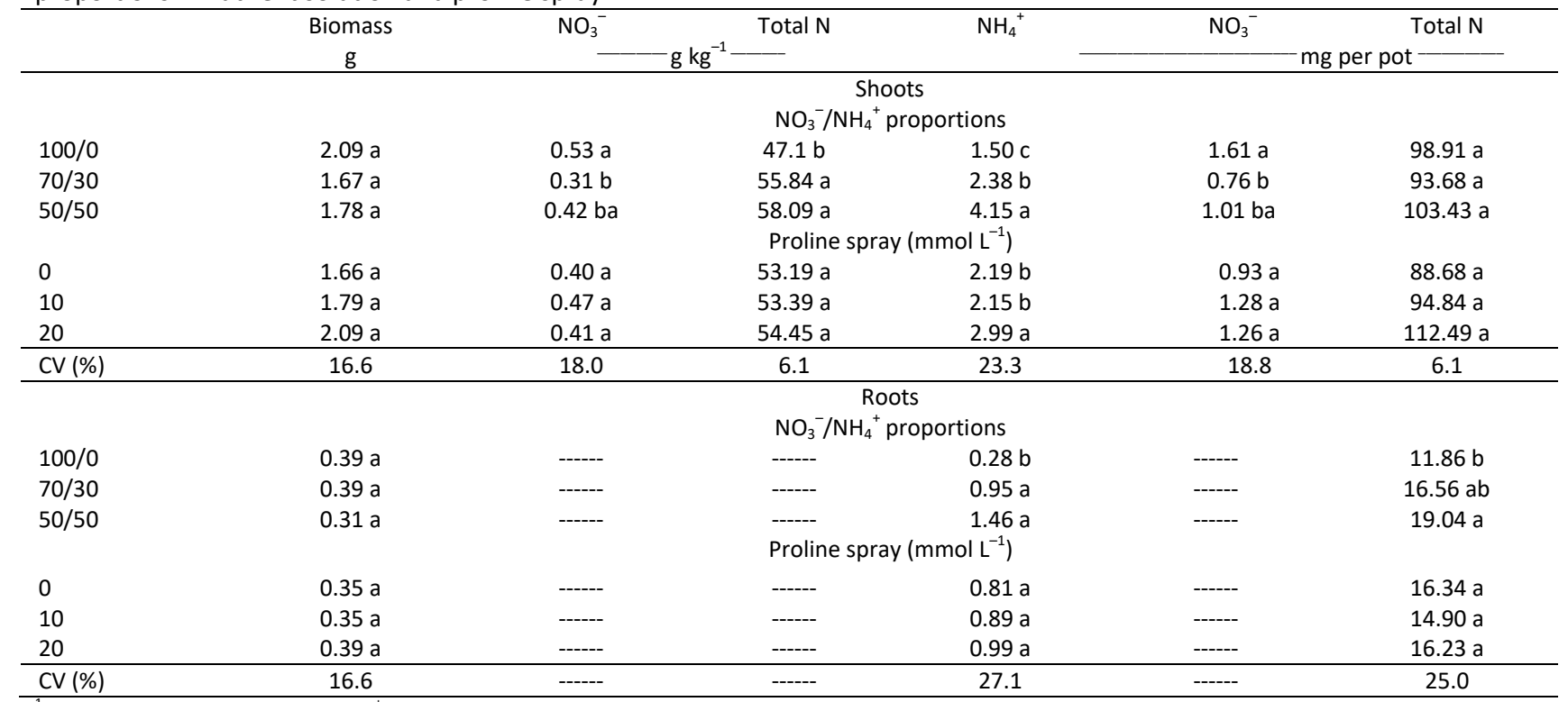

${ }^{1}$ Lowercase letters compare $\mathrm{NO}_{3}{ }^{-} / \mathrm{NH}_{4}{ }^{+}$proportions or proline spray in each sub-column. Dotted line - parameters with significant interaction. The means were compared by Tukey's test at $5 \%$ significance.
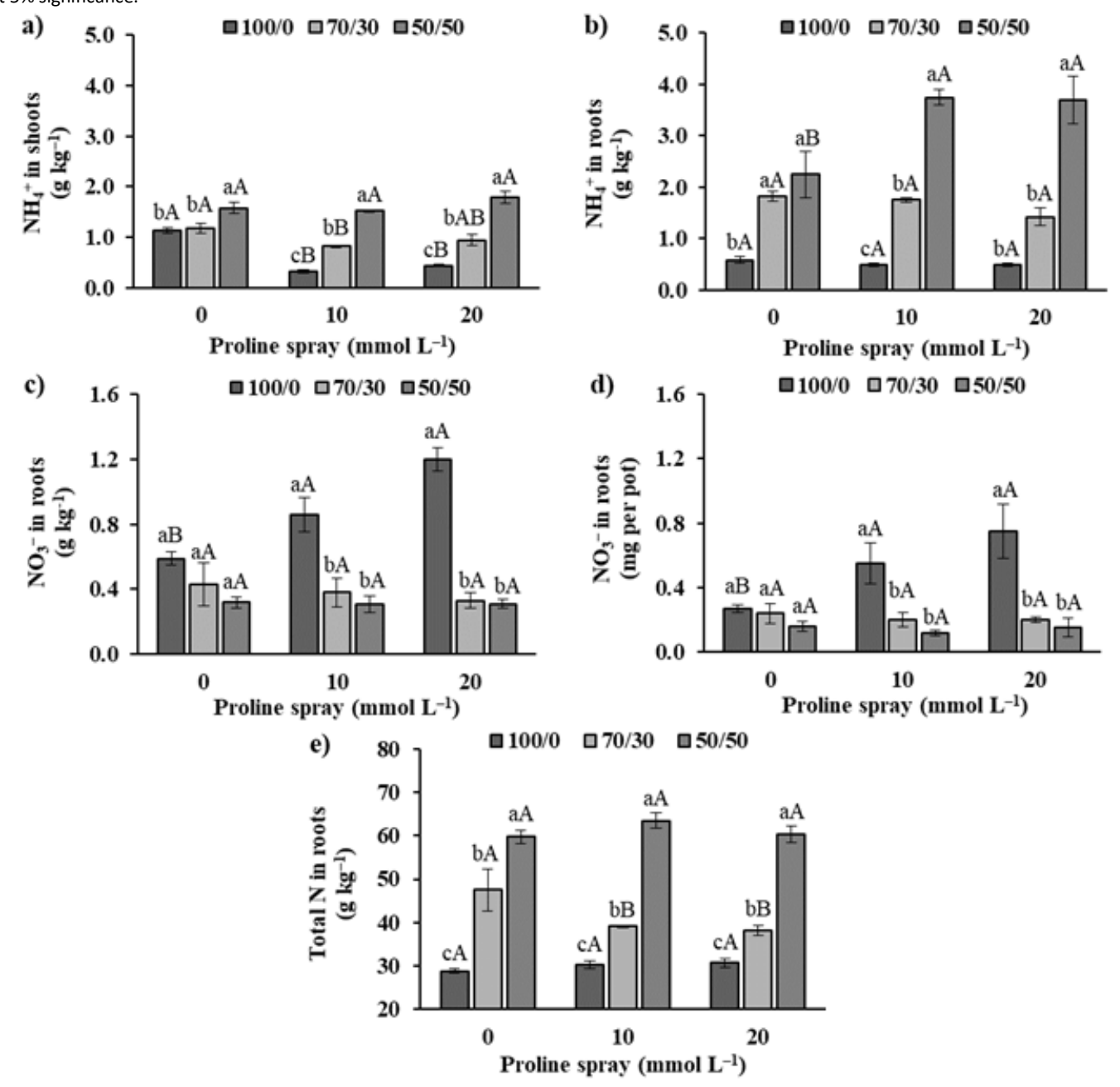

Fig 1. Concentration of $\mathrm{NH}_{4}{ }^{+}, \mathrm{NO}_{3}{ }^{-}$, and total $\mathrm{N}$ in shoots and roots of tomato plants as a function of proline spray and $\mathrm{NO}_{3}{ }^{-} / \mathrm{NH}_{4}{ }^{+}$ proportions in nutrient solution. Lowercase letters compare $\mathrm{NO}_{3}{ }^{-} / \mathrm{NH}_{4}{ }^{+}$proportions within each proline rate and uppercase letters compare proline rates within $\mathrm{NO}_{3}{ }^{-} / \mathrm{NH}_{4}{ }^{+}$proportions. Coefficient of variation (\%) = 23.3 (a), 17.5 (b), 25.5 (c), 20.5 (d) and 8.1 (e). Error bars represent standard error. 
Table 2. Proline concentration, antioxidant enzyme activity in the shoots and roots, leaf photosynthesis, and biomass of the tomato plants under $\mathrm{NO}_{3}{ }^{-} / \mathrm{NH}_{4}{ }^{+}$proportions in nutrient solution and proline spray ${ }^{1}$

\begin{tabular}{|c|c|c|c|c|c|c|c|}
\hline & $\begin{array}{l}\text { Proline } \\
\mu \mathrm{mol} \mathrm{g}{ }^{-1} \mathrm{FW}\end{array}$ & GR & $\begin{array}{c}\text { CAT } \\
-\mu \mathrm{mol} \mathrm{min}^{-1} \mathrm{mg}^{-1}\end{array}$ & $\begin{array}{c}\text { GPOX } \\
\text { protein-------- } \\
\end{array}$ & $\begin{array}{l}\text { A } \\
\mu \mathrm{mol} \mathrm{m} \mathrm{m}^{-2} \mathrm{~s}^{-1}\end{array}$ & $\begin{array}{l}\mathrm{SC} \\
\mathrm{mmol} \mathrm{m}{ }^{-2} \mathrm{~s}^{-1}\end{array}$ & $\begin{array}{l}\text { SPAD } \\
\text { Value }\end{array}$ \\
\hline & \multicolumn{7}{|c|}{$\begin{array}{c}\text { Shoot } \\
\text { Shortions }\end{array}$} \\
\hline $100 / 0$ & $2.32 \mathrm{a}$ & $0.37 b$ & 260.04 a & $37.46 \mathrm{a}$ & $9.46 b$ & $82.57 \mathrm{~b}$ & $30.44 \mathrm{c}$ \\
\hline $70 / 30$ & $2.14 \mathrm{a}$ & $1.03 \mathrm{a}$ & $230.83 \mathrm{a}$ & $39.84 \mathrm{a}$ & $12.33 \mathrm{a}$ & $145.74 \mathrm{a}$ & $38.88 \mathrm{~b}$ \\
\hline $50 / 50$ & $1.85 \mathrm{a}$ & $1.06 \mathrm{a}$ & $99.50 \mathrm{~b}$ & $30.10 \mathrm{a}$ & $12.49 \mathrm{a}$ & $139.01 \mathrm{a}$ & $43.88 \mathrm{a}$ \\
\hline & \multicolumn{7}{|c|}{ Proline spray $\left(\mathrm{mmol} \mathrm{L}^{-1}\right)$} \\
\hline 0 & $1.33 \mathrm{~b}$ & $1.02 \mathrm{a}$ & 169.07 b & $26.20 \mathrm{~b}$ & $10.87 \mathrm{a}$ & $114.18 \mathrm{a}$ & $37.66 \mathrm{a}$ \\
\hline 10 & $2.16 \mathrm{a}$ & $0.71 \mathrm{a}$ & $178.42 \mathrm{ab}$ & $34.62 \mathrm{ab}$ & $11.21 \mathrm{a}$ & $120.09 \mathrm{a}$ & $38.11 \mathrm{a}$ \\
\hline 20 & $2.82 \mathrm{a}$ & $0.73 \mathrm{a}$ & $242.88 \mathrm{a}$ & $46.75 \mathrm{a}$ & $12.20 \mathrm{a}$ & $133.06 \mathrm{a}$ & $37.44 \mathrm{a}$ \\
\hline CV (\%) & 31.6 & 39.8 & 27.8 & 43.2 & 22.6 & 43.3 & 3.4 \\
\hline
\end{tabular}

\begin{tabular}{|c|c|c|c|c|c|c|c|}
\hline \multirow[b]{2}{*}{ 100/0 } & \multicolumn{7}{|c|}{$\mathrm{NO}_{3}{ }^{-} / \mathrm{NH}_{4}{ }^{+}$proportions } \\
\hline & $2.12 \mathrm{a}$ & $3.11 \mathrm{a}$ & $845.98 \mathrm{a}$ & 217.78 a & ------- & ------- & ------- \\
\hline $70 / 30$ & $1.42 \mathrm{~b}$ & $3.98 \mathrm{a}$ & $844.00 \mathrm{a}$ & $198.74 a b$ & ------- & ------ & ------ \\
\hline \multirow[t]{2}{*}{$50 / 50$} & $0.71 \mathrm{c}$ & $1.36 \mathrm{~b}$ & $710.32 \mathrm{a}$ & 153.57 b & ------ & ------ & ------ \\
\hline & \multicolumn{7}{|c|}{ Proline spray $\left(\mathrm{mmol} \mathrm{L}^{-1}\right)$} \\
\hline 0 & $1.28 \mathrm{a}$ & $3.51 \mathrm{a}$ & $856.45 \mathrm{a}$ & 211.73 a & ------ & ------ & ------ \\
\hline 10 & $1.51 \mathrm{a}$ & $2.98 a b$ & $761.34 \mathrm{a}$ & 184.58 a & ------- & ------- & ------- \\
\hline 20 & $1.46 \mathrm{a}$ & $2.12 \mathrm{~b}$ & $782.52 \mathrm{a}$ & 173. $78 \mathrm{a}$ & ------ & ------ & ------ \\
\hline CV (\%) & 39.0 & 32.5 & 22.8 & 21.8 & +------ & ------- & ------ \\
\hline
\end{tabular}

${ }^{1}$ Lowercase letters compare $\mathrm{NO}_{3}{ }^{-} / \mathrm{NH}_{4}{ }^{+}$proportions or proline rates in each sub-column. $\mathrm{FW}=$ fresh weight; $\mathrm{GR}=$ glutathione reductase; $\mathrm{CAT}=\mathrm{catalase} ; \mathrm{A}=\mathrm{CO}{ }_{2}$ assimilation rate; $\mathrm{SC}=$ stomatal conductance; $\mathrm{CV}=$ coefficient of variation. Dotted line - parameters with significant interaction. The means were compared by Tukey's test at $5 \%$ significance.
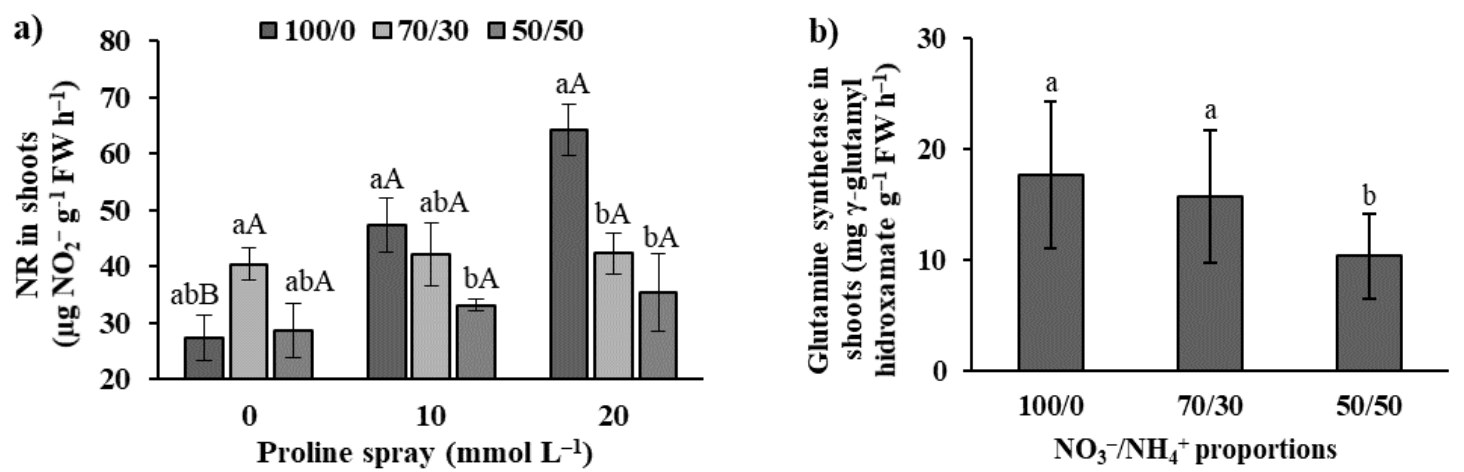

Fig 2. Nitrate reductase (NR) and glutamine synthetase (GS) activities in shoots of tomato plants as a function of proline spray and $\mathrm{NO}_{3}{ }^{-} / \mathrm{NH}_{4}{ }^{+}$proportions in nutrient solution. Lowercase letters compare $\mathrm{NO}_{3}{ }^{-} / \mathrm{NH}_{4}{ }^{+}$proportions within each proline rate and uppercase letters compare proline rates within $\mathrm{NO}_{3}{ }^{-} / \mathrm{NH}_{4}{ }^{+}$proportions. Coefficient of variation (\%) $=21.8$ (a) and 20.4 (b). Error bars represent standard error.
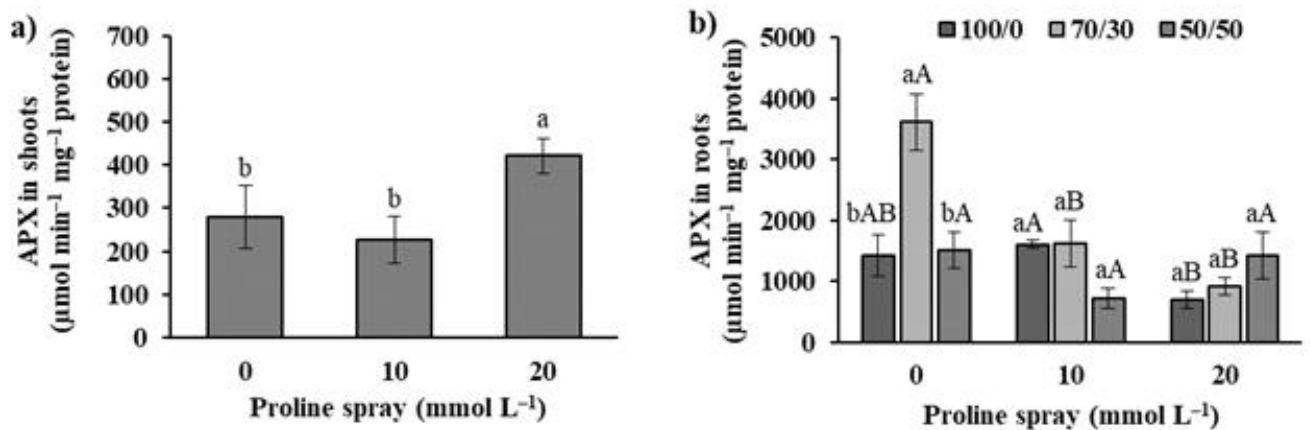

Fig 3. Ascorbate peroxidase (APX) activity in shoots and roots of tomato plants as a function of proline $\mathrm{spray}^{\mathrm{and}} \mathrm{NO}_{3}{ }^{-} / \mathrm{NH}_{4}^{+}$ proportions in nutrient solution. Lowercase letters compare $\mathrm{NO}_{3}{ }^{-} / \mathrm{NH}_{4}{ }^{+}$proportions within each proline rate and uppercase letters compare proline rates within $\mathrm{NO}_{3}{ }^{-} / \mathrm{NH}_{4}{ }^{+}$ratios. Coefficient of variation (\%) $=23.3$ (a) and 17.5 (b). Error bars represent standard error. 

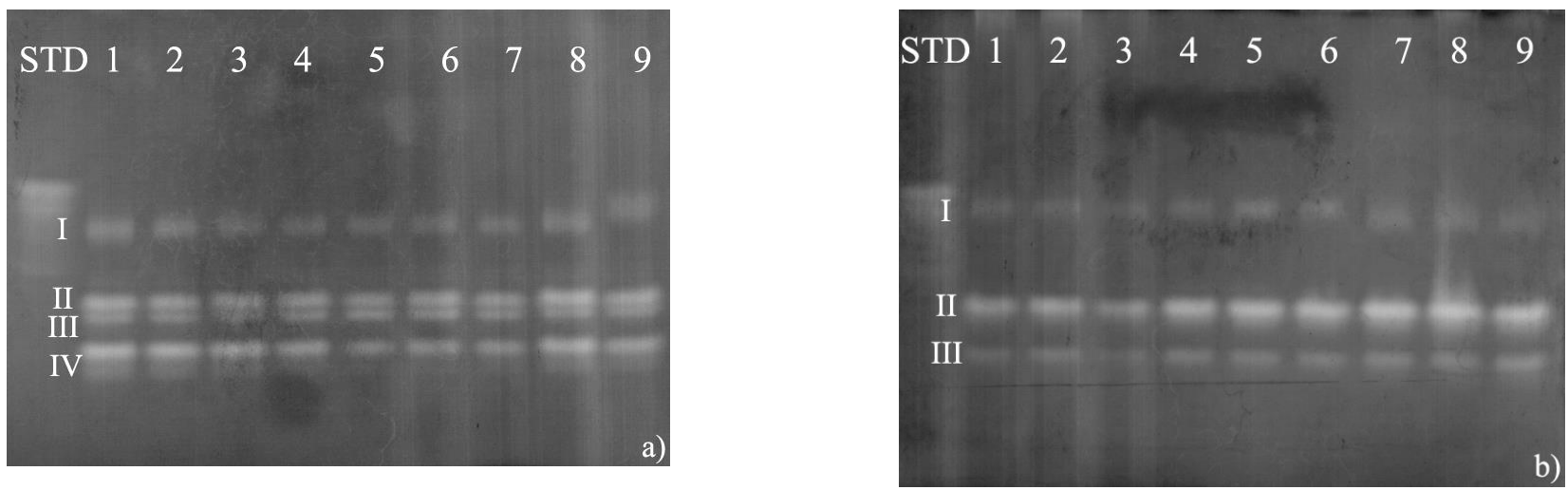

Fig 4. Superoxide dismutase (SOD) activity in shoots and roots of tomato plants as a function of proline rates and $\mathrm{NO}_{3}{ }^{-} / \mathrm{NH}_{4}{ }^{+}$ proportions in nutrient solution. 1 to $3=100 / 0 \mathrm{NO}_{3}{ }^{-} / \mathrm{NH}_{4}{ }^{+} ; 4$ to $6=70 / 30 \mathrm{NO}_{3}{ }^{-} / \mathrm{NH}_{4}{ }^{+} ; 7$ to $9=50 / 50 \mathrm{NO}_{3}{ }^{-} / \mathrm{NH}_{4}{ }^{+} ; 1,4$, and $7=0$ mmol L $\mathrm{mroline}^{-1}, 5$, and $8=10 \mathrm{mmol} \mathrm{L}^{-1}$ proline; 3,6 , and $9=20 \mathrm{mmol} \mathrm{L}^{-1}$ proline; I, II, III and IV are critical bands of SOD; STD = bovine SOD standard.

In the roots, proline application decreased APX activity in plants grown under $100 / 0$ and $70 / 30 \mathrm{NO}_{3}{ }^{-} / \mathrm{NH}_{4}{ }^{+}$, but not in plants grown under $50 / 50 \mathrm{NO}_{3}^{-} / \mathrm{NH}_{4}^{+}$(Fig. 3b).

Higher band intensity of SOD suggests higher enzyme activity (Figure 4). Four SOD isoforms were detected in the shoots, and the bands were more intense at the $100 / 0$ and

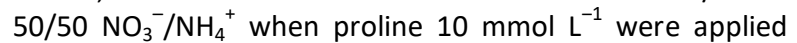
(isoforms II and IV) (Figure 4a). Three SOD isoforms (I, II, and IV) were detected in the roots, and the band intensities were amplified as the $\mathrm{NH}_{4}^{+}$concentrations in the nutrient solution increased (Figure 4b). Isoform II and III was practically undetectable in the tomato roots (Figure 4b).

\section{Discussion}

The roots became more branched when $\mathrm{NH}_{4}{ }^{+}$was supplied in the nutrient solution. The shortened roots and reduced biomass are clearly two phenotypic traits occurring in plants receiving a high supply of $\mathrm{NH}_{4}{ }^{+}$(Loqué and von Wiren, 2004; Liu et al., 2013). Studies have shown that $N$ availability is strongly associated with root branching, and that this limits the development of the primary root (Zhang and Forde, 2000; Lima et al., 2010; Chapman et al., 2011). The $\mathrm{NO}_{3}{ }^{-}$ supply significantly affects the growth and development of roots (Gojon et al., 2011), and there are indications that the $\mathrm{N}$ supply in the forms of both $\mathrm{NO}_{3}{ }^{-}$and $\mathrm{NH}_{4}{ }^{+}$has complementary effects on root architecture (Lima et al., 2010).

Proline is necessary for protein synthesis, in addition to being a precursor for the synthesis of glutamate (Alyemeni et al., 2016), one of the $\mathrm{NH}_{4}{ }^{+}$assimilation products by GS that play a role in the regulation and development of lateral roots. This is believed to be an adaptation of the plants that increases their ability to seek $\mathrm{N}$, which affects the uptake of this nutrient (Liu et al., 2006). Nevertheless, in the present study the tested factors did not appear to influence the root dry mass, which might be a consequence of the short growth period of the tomato plant in the growth chamber, since this species has greater development during the reproduction stage, a period when maximal differentiation of phenotype mass occurs.

The higher $\mathrm{NO}_{3}{ }^{-}$concentration and accumulation in the shoots at the $\mathrm{NO}_{3}{ }^{-} / \mathrm{NH}_{4}{ }^{+}$proportion of $100 / 0$, without the influence of proline (Figure 1 and Table 1), is a result of the high concentration of this ion in the nutrient solution. In this situation, the entire $\mathrm{N}$ supply is in the $\mathrm{NO}_{3}{ }^{-}$form, which explains the high concentrations of this ion in the plant. Proline is an excellent osmoregulator, which explains the maintenance of $\mathrm{NO}_{3}{ }^{-}$in the roots and the high NR activity in plants supplied with exogenous proline (Hayat et al., 2012). The NR activity at the $100 / 0 \quad \mathrm{NO}_{3}{ }^{-} / \mathrm{NH}_{4}{ }^{+}$increased as the proline rates increased (Figure 2), because proline has the ability to maintain the integrity of the protein and enzyme activity is significant (Hayat et al., 2012). The NR enzyme is induced by the $\mathrm{NO}_{3}{ }^{-}$presence in the substrate (Alyemeni et al., 2016), and this enzyme activity has been frequently associated with the $\mathrm{NO}_{3}{ }^{-}$concentration in leaf tissues (Jampeetong and Brix, 2009), as observed in the present study.

The exogenous proline application at rate of $20 \mathrm{mmol} \mathrm{L}^{-1}$ was also shown to increased NR activity by $29.3 \%$ in chickpea plants (Cicer arietinum). Teh et al. (2016) showed that $\mathrm{N}$ assimilation in rice plants (Oryza sativa) treated with exogenous proline ( 5 and $10 \mathrm{mmol} \mathrm{L}^{-1}$ ) also displayed higher NR activity in shoots when compared to plants that were not sprayed with proline. This indicates that exogenous proline may increase $\mathrm{NR}$ activity in plants.

The higher $\mathrm{NH}_{4}^{+}$concentration and accumulation in the shoots with the $50 / 50 \mathrm{NO}_{3}{ }^{-} / \mathrm{NH}_{4}{ }^{+}$proportion and proline spray (Figure 1 and Table 1) may be due to the effect of proline on the $\mathrm{N}$ assimilation metabolism under high $\mathrm{NH}_{4}^{+}$ concentrations. Since no effects on plant biomass production were observed, increases in concentration and accumulation of minerals cannot be associated with dilution effects. The $\mathrm{NO}_{3}{ }^{-}$reduction process is complex and has a high energy cost for plants when $\mathrm{N}$ is provided exclusively as $\mathrm{NO}_{3}{ }^{-}$(Guo et al., 2007). However, in this study, the proline application in the plants induced $\mathrm{NH}_{4}{ }^{+}$accumulation because the key enzyme incorporating this ion into glutamine did not show variations in activity as the proline rates changed. Proline application stimulated high $\mathrm{NO}_{3}{ }^{-}$absorption in the roots of the tomato plant. Consequently, NR activity was high within the shoots as this enzyme was able to assimilate large amounts of $\mathrm{NO}_{3}{ }^{-}$, which can become toxic at high levels (Chapman et al., 2011). Results from this study suggest that the tomato plant was not able to increase the GS activity in order to assimilate the reduced $N$, which explains the higher $\mathrm{NH}_{4}{ }^{+}$concentrations and accumulation found in plants sprayed with proline. 
When plants are supplied with $\mathrm{NH}_{4}^{+}$in the nutrient solution rather than $\mathrm{NO}_{3}{ }^{-}$as a $\mathrm{N}$ source, there is an upward trend in GS activity (Mihaljević et al., 2011). That the highest activities of NR and GS enzymes were detected in plants supplied with $\mathrm{N}$ as $\mathrm{NO}_{3}{ }^{-}$exclusively may be associated with low net photosynthesis and stomatal conductance, and suggests that high activity of these enzymes is unfavorable for plant photosynthesis. As a result, the demand for carbon skeletons to incorporate the excess $\mathrm{NH}_{4}^{+}$was not attended, which led to a higher $\mathrm{NH}_{4}{ }^{+}$concentration in these plants and a low photosynthetic rate (Schortemeyer et al., 1997). Research has shown that the GS enzyme is key in the proline synthesis of tobacco plants (Nicotiana plumbaginifolia) because when supplied with abundant $\mathrm{NH}_{4}{ }^{+}$, plants were shown to express low GS enzyme activity, and exhibited a lower proline content in the plant tissue. Teh et al. (2016) also found no difference in the GS activity in rice plants sprayed with proline $10 \mathrm{mmol} \mathrm{L}^{-1}$, but found that exogenous proline increased the NR activity by many fold. In the shoots, the highest total $\mathrm{N}$ concentration in the roots was found in plants with $50 / 50 \mathrm{NO}_{3}{ }^{-} / \mathrm{NH}_{4}{ }^{+}$proportion at each proline rate, and the accumulation was lowest in plants with $100 / 0 \mathrm{NO}_{3}{ }^{-} / \mathrm{NH}_{4}{ }^{+}$proportions, with no differences observed between the proline spray treatments. According to Liu et al. (2017), the total $\mathrm{N}$ concentration in tomato plants is affected by $\mathrm{NO}_{3}{ }^{-} / \mathrm{NH}_{4}{ }^{+}$proportions, and as $\mathrm{NO}_{3}{ }^{-}$concentrations in the $\mathrm{N}$ fertilizer increases, the total $\mathrm{N}$ concentration decreases. Konnerup and Brix (2010) also concluded that as the $\mathrm{NO}_{3}{ }^{-}$ participation in the $\mathrm{NO}_{3}{ }^{-} / \mathrm{NH}_{4}{ }^{+}$proportion is raised, the $\mathrm{N}$ content in stems, leaves, and fruits of the pepper plant (Capsicum annuum) decreases. Some studies have investigated the effect of the $\mathrm{NO}_{3}{ }^{-} / \mathrm{NH}_{4}{ }^{+}$proportions on photosynthesis, one of the most important physiologic processes affected by $\mathrm{N}$ forms (Guo et al., 2007a,b; Cruz et al., 2014). However, there are few studies showing the effects of the combination of $\mathrm{NO}_{3}{ }^{-}$and $\mathrm{NH}_{4}{ }^{+}$compared to the exclusive supply of $\mathrm{NO}_{3}^{-}$on the optimization of the photosynthetic process. The highest net photosynthesis and stomatal conductance rates under supply with $\mathrm{NO}_{3}{ }^{-}$and $\mathrm{NH}_{4}{ }^{+}$may be a result of the high $\mathrm{NH}_{4}{ }^{+}$concentration in the plant, which also reflected the leaf chlorophyll content and hence high photosynthetic rate (Liu et al., 2017). It has been reported that the $\mathrm{NH}_{4}{ }^{+}$concentration in the culture medium is beneficial to the growth and photosynthesis of some species such as rice (Guo et al., 2007a; Li et al., 2009), mainly because of the increased rubisco activity, which enhances the carboxylation efficiency. Cruz et al. (2014) observed increased photosynthesis in cassava plants (Manihot esculenta) as the $\mathrm{NH}_{4}^{+}$rates supply was increased, which may be an effect of the high chlorophyll content stemming from the suitable $\mathrm{N}$ supply. Liu et al. (2017) observed a decrease in net photosynthesis and a chlorophyll content with tomato plants grown under $\mathrm{N}$ as $\mathrm{NO}_{3}{ }^{-}$compared with plants grown under both $\mathrm{NO}_{3}^{-}$and $\mathrm{NH}_{4}^{+}$. The chlorophyll content can be used as an indicator of the $\mathrm{N}$ nutrition, and an imbalance in this fertilization can generate stress, negatively affecting the chlorophyll synthesis and hence photosynthesis. Under normal conditions of plant growth, antioxidant components are activated by plants to promote its maximal development inasmuch as they are able to eliminate reactive oxygen species (ROS) generated by adverse environmental conditions (Ghanbari and Sayyari, 2018). However, when plants are exposed to nutritional imbalance, ROS production may be increased (Nogueirol et al., 2016). In plants grown in the field, increased activity of the antioxidant enzyme system provides better development, which has been reported for several plant species (Yang et al., 2011). The CAT and GR enzyme activities were higher in the tomato shoots when $\mathrm{N}$ was supplied in a large proportion as $\mathrm{NO}_{3}{ }^{-}$(Table 2). This suggests that $\mathrm{NO}_{3}{ }^{-}$ acts as an important mineral signaling the antioxidant system in the tomato plant.

The CAT, GPOX, and APX enzyme activity in the tomato shoots increased with exogenous proline application (Table 2 and Figure 3). This suggests that proline acts as a protector and enzymatic activator inasmuch as the 3-D structure of proteins (enzymes) is governed by hydrophobic/hydrophilic interactions that act in the lateral chains of amino acids, especially proline. Because it interferes with these lateral chains, proline plays a protective role, increasing the activity of the enzymes and acting as a strong enzymatic activator of the antioxidant system (Alyemeni et al., 2016). In some cases, an interaction occurs between proline and the carbonic anhydrase that can heighten the activity of this enzyme. The activity of the GR and APX enzymes in the root tissues decreased with exogenous proline application on the leaves (Table 2) probably because proline acted as an important regulator of the antioxidant enzymatic functions, activating or inhibiting enzymes according to the metabolic need of the specific part of the plant. Another important part of the antioxidant system of the plant is the maintenance of the ascorbate-glutathione cycle. Exogenous proline supply to the plants increased the activity of the enzymes of the ascorbate-glutathione cycle as in the case of this study, where the APX activity increased with increasing proline supply (Hoque et al., 2007). In the plant shoots, the influence of proline application $\left(10 \mathrm{mmol} \mathrm{L}^{-1}\right)$ was significant evident on the SOD activity (Figure 4a). In addition to increasing the activity of the enzymes of the antioxidant system (CAT and SOD), exogenous proline application also increases the activity of other enzymes such as NR (Hoque et al., 2007), as was found in this study. However, the $\mathrm{NH}_{4}^{+}$ increase in the nutrient solution changed the intensity of bands of this enzyme in the roots (Figure 4b). The supply of part of $\mathrm{N}$ as $\mathrm{NH}_{4}^{+}$in the growth medium resulted in increased production of metabolic energy that was directed for induction of higher SOD activity. Plants with high SOD activity have a greater ability of tolerate many adverse conditions and this is desirable for major crops around the world, like tomato, especially in a condition of climate change that induces environmental stress conditions.

\section{Materials and Methods}

\section{Plant materials}

The commercial tomato (Solanum lycopersicum) hybrid Serato F1 was used in this experiment. Tomato seeds were germinated on plastic trays containing sand washed with deionized water.

\section{Treatments}

Exogenous proline was applied via leaf spraying at a rate of 0,10 , and $20 \mathrm{mmol} \mathrm{L}^{-1}$ in a $30 \mathrm{~mL}$ of solution per pot. The $\mathrm{NO}_{3}{ }^{-} / \mathrm{NH}_{4}{ }^{+}$proportions were $100 / 0,70 / 30$, and $50 / 50$ in nutrient solution with $\mathrm{N}$ of $15 \mathrm{mmol} \mathrm{L}^{-1}$. 


\section{Experimental design and conduction of experiment}

The experiment was carried out in a completely randomized block design with a factorial arrangement $3 \times 3$ (proline spray $\times \mathrm{NO}_{3}{ }^{-} / \mathrm{NH}_{4}{ }^{+}$proportions) with six replications (three used for the nutritional and productive assessments and the other three for metabolic and physiologic determinations). The experiment was carried out in an experimental growth chamber with photosynthetically active radiation of 400 $\mu \mathrm{mol} \mathrm{m} \mathrm{m}^{-2} \mathrm{~s}^{-1}$ and temperature of $27 \circ \mathrm{C}$. To prevent contamination of the nutrient solution and the leaves with the proline spray, the pots were capped and the leaves washed with deionized water. The 50/50 $\mathrm{NO}_{3}{ }^{-} / \mathrm{NH}_{4}{ }^{+}$ proportions were included to represent a fertilizer with equal proportions of $\mathrm{NO}_{3}{ }^{-}$and $\mathrm{NH}_{4}{ }^{+}$, as occurs in ammonium nitrate.

After 17 days of the tomato seeds germinated, when seedlings had reached around $4 \mathrm{~cm}$ in height, three seedlings were transplanted into each pot containing Hoagland and Arnon (1950) nutrient solution at $20 \%$ ionic strength of the pre-established $\mathrm{NO}_{3}{ }^{-} / \mathrm{NH}_{4}{ }^{+}$proportions. Plants were allowed to become established in the new pots and only given water during the next three days. Thereafter, plants were grown for 15 days with nutrient solution at $100 \%$ ionic strength, with the nutrient solution being renewed every seven days to prevent the transformation of $\mathrm{NH}_{4}{ }^{+}$into $\mathrm{NO}_{3}{ }^{-}$. Exogenous proline was then applied to the leaves of the plants for one a single day, waiting for 10 days the proline effect before being collected and the roots and shoots separated for analysis.

\section{Traits measured}

\section{Biomass production}

The collected shoots and roots were dried in a forced-air oven at $65^{\circ} \mathrm{C}$ for $72 \mathrm{~h}$ and dry mass of each part was grounded in a Wiley mill and weighed.

\section{Indirect evaluation of the chlorophyll content}

The indirect measurement of chlorophyll content was assessed through SPAD index readings using a SPAD-502 MINOLTA portable equipment. Readings were taken in the medium portion of the leaf, in five leaves per experimental unit.

\section{Concentrations of total $\mathrm{N}, \mathrm{NO}_{3}^{-}$, and $\mathrm{NH}_{4}^{+}$}

The dry mass of shoots and roots was digested with sulfuric acid, according to Malavolta et al. (1997). Concentrations of $\mathrm{NO}_{3}{ }^{-}$and $\mathrm{NH}_{4}^{+}$were determined after extraction with $\mathrm{KCl} 1$ $\mathrm{mol} \mathrm{L}^{-1}$, according to Tedesco et al. (1985). In all cases, the concentrations were obtained after distillation in a micro Kjeldahl distilling apparatus and titration with a diluted sulfuric acid solution.

\section{Proline concentration}

Based on procedures from Bates et al. (1973), samples were homogenized in sulfosalicylic acid $30 \mathrm{~g} \mathrm{~L}^{-1}$ and centrifuged at $10,000 \mathrm{rpm}$ for $20 \mathrm{~min}$ at 15 으. Thereafter, extracts were allowed to react with ninhydrin $25 \mathrm{~g} \mathrm{~L}^{-1}$, phosphoric acid 6 $\mathrm{mol} \mathrm{L}^{-1}$, and glacial acetic acid, at 100 으 $\mathrm{C}$ for $1 \mathrm{~h}$. Afterwards, concentrated toluene was added, and tubes were shaken. Proline was quantified in a spectrophotometer at $520 \mathrm{~nm}$.

\section{Nitrogen metabolism enzymes}

\section{Nitrate reductase (NR, EC. 1.7.1.1)}

NR activity was quantified according Mulder et al. (1959). The test was based on $\mathrm{NO}_{2}{ }^{-}$production by leaves of the tomato plant under phosphate buffer $(\mathrm{pH} 7)$ and $\mathrm{HNO}_{3} 0.025$ $\mathrm{mol} \mathrm{L}^{-1}$ at $35^{\circ} \mathrm{C}$ for $2 \mathrm{~h}$. A solution of alpha-naphthylamine (NED), $10 \mathrm{~g} \mathrm{~L}^{-1}$ sulfanilamide, and sodium acetate was added to paralyze the enzyme activity. The $\mathrm{NO}_{2}^{-}$produced was quantified in a spectrophotometer at $540 \mathrm{~nm}$.

\section{Glutamine synthetase (GS, EC. 6.3.1.2)}

The GS activity was quantified using the methodology of Elliott (1953). Leaf portions previously macerated with Tris$\mathrm{HCl}$ solution were used and the extract was centrifuged at $10,000 \mathrm{rpm}$ at 4 ㅇ $\mathrm{C}$ for $10 \mathrm{~min}$ and later incubated. After the incubation period, the activity was paralyzed and the enzyme activity was quantified based on the production of $\lambda$-glutamyl hydroxamate in a spectrophotometer at $540 \mathrm{~nm}$.

\section{Antioxidant enzymes and soluble protein}

The extraction for enzymatic analyses was performed according to the adapted methodology of Azevedo et al. (1998), and the concentration of soluble proteins was quantified following Bradford (1976).

\section{Catalase (CAT, EC 1.11.1.6)}

The CAT activity was quantified according to Cakmak and Horst (1991), using a mixture of $100 \mathrm{mmol} \mathrm{L}^{-1}$ potassium phosphate buffer $(\mathrm{pH} 7.5)$ and $30 \% \mathrm{H}_{2} \mathrm{O}_{2}$ with addition of the protein extract. The activity was determined by the decomposition of $\mathrm{H}_{2} \mathrm{O}_{2}$ for $1 \mathrm{~min}$ at $240 \mathrm{~nm}$.

\section{Ascorbate peroxidase (APX, EC 1.11.1.11)}

The APX activity was determined according to the method of Cakmak and Horst (1991), with the extract readings conducted at $290 \mathrm{~nm}$. The solution containing $80 \mathrm{mmol} \mathrm{L}^{-1}$ potassium phosphate buffer $(\mathrm{pH} 7.0)+5 \mathrm{mmol} \mathrm{L}^{-1}$ ascorbate $+1 \mathrm{mmol} \mathrm{L}^{-1}$ EDTA, $1 \mathrm{mmol} \mathrm{L}^{-1} \mathrm{H}_{2} \mathrm{O}_{2}$, and protein extract in a

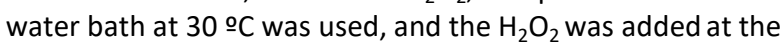
time of the reading.

\section{Superoxide dismutase (SOD, EC 1.15.1.1)}

Non-denaturing polyacrylamide gel (12\%) (PAGE) was produced. A bovine SOD standard was added to each gel, which was stained with nitroblue tetrazolium (NBT) and riboflavin (Réndon et al. 2013).

\section{Guaiacol peroxidase (GPOX, 1.11.1.7)}

The GPOX activity was determined by the method of Matsuno and Uritani (1974). The reaction medium 
containing phosphate-citrate buffer $(\mathrm{pH} \mathrm{5),} \mathrm{guaiacol,} \mathrm{and}$ protein extract was incubated at $30^{\circ} \mathrm{C}$ for $15 \mathrm{~min}$. The reaction was paralyzed with an ice bath and $20 \mathrm{~g} \mathrm{~L}^{-1}$ sodium metabisulphite and readings were performed at $450 \mathrm{~nm}$ (Gomes Junior et al., 2006).

\section{Glutathione reductase (GR, EC 1.6.4.2)}

The GR activity was quantified at a wavelength of $412 \mathrm{~nm}$. Protein extract was added to the reaction mixture containing $100 \mathrm{mmol} \mathrm{L}^{-1}$ potassium phosphate buffer $(\mathrm{pH} 7.5), 3 \mathrm{mmol}$ $\mathrm{L}^{-1} 5,5^{\prime}$-dithio-bis-2-nitrobenzoic acid (DTNB), $20 \mathrm{mmol} \mathrm{L}^{-1}$ oxidized glutathione, and $2 \mathrm{mmol} \mathrm{L}^{-1} \mathrm{NADPH}$ at $30 \circ \mathrm{C}$, and the activity was estimated by the oxidized glutathione reduction (Gratão et al., 2008).

\section{Statistical analysis}

Analysis of variance was performed, applying the ANOVA procedure and the $F$ test. When the interaction was significant, the factors were decomposed and means were compared by Tukey's test at $5 \%$ significance. When the interaction was not significant, factors were evaluated separately and means were compared by Tukey's test at $5 \%$ significance (SAS, 2004).

\section{Conclusion}

The exogenous proline applied to the tomato plants increased NR activity, mineral uptake and antioxidant activity, but did not affect GS activity, photosynthesis, chlorophyll content, or biomass production. Despite the different $\mathrm{NO}_{3}{ }^{-} / \mathrm{NH}_{4}{ }^{+}$solutions not affecting the biomass production of the tomato plants; $\mathrm{NH}_{4}{ }^{+}$in nutrient solution increased photosynthesis, antioxidant activity, and chlorophyll content. This effect is favorable for crops with economic relevance such the tomato. Thus, producers considering the use of exogenous proline to increase yields and efficiency of $\mathrm{N}$ should first consider the $\mathrm{NO}_{3}{ }^{-} / \mathrm{NH}_{4}{ }^{+}$ proportions in which the plants are grown.

\section{Acknowledgments}

Authors thank Coordenação de Aperfeiçoamento de Pessoal de Nivel Superior (CAPES) (R.C.N) and Fundação de Amparo à Pesquisa do Estado de São Paulo (FAPESP) (J.C.S.J) for the scholarship granted and Conselho Nacional de Desenvolvimento Científico e Tecnológico (CNPq) (F.A.M, D.D.N and S.C.M) for the fellowship and for the scholarship granted.

\section{References}

Alyemeni MN, Hayat Q, Hayat S, Faizan M, Faraz A (2016). Exogenous proline application enhances the efficiency of nitrogen fixation and assimilation in chickpea plants exposed to cadmium. Legume Res. 39:221-227.

Azevedo RA, Alas RM, Smith RJ, Lea PJ (1998). Response from elevated carbon dioxide to air and ozone fumigation in leaves and roots of wild type and a catalase-deficient mutant of barley. Physiol Plantarum. 104:280-292.
Bates LS, Waldren RP, Teare ID (1973) Rapid determination of free proline for water-stress studies. Plant Soil. 39:205207.

Boczulak SA, Hawkins BJ, Roy R (2014) Temperature effects on nitrogen form uptake by seedling roots of three contrasting conifers. Tree Physiol. 34:513-523.

Bradford MM (1976) A rapid and sensitive method for the quantification of microgram quantities of protein utilizing the principles of protein-dye binding. Anal Biochem. 71:248-254.

Britto DT, Kronzucker HJ (2013) Ecological significance and complexity of $\mathrm{N}$-source preference in plants. Ann Bot. 112:957-963.

Cakmak I, Horst WJ (1991) Effect of aluminium on lipid peroxidation, superoxide dismutase catalase and peroxidase activities in root tips of soybean (Glycine max). Physiol Plantarum. 83:463-468.

Chapman N, Whalley WR, Lindsey K, Miller AJ (2011) Water supply and not nitrate concentration determines primary root growth in Arabidopsis. Plant Cell Environ. 34:16301638.

Chen ZX, Li FL, Yang SN, Dong YB, Yuan QH, Wang F, Li WM, Jiang $Y$, Jia SR, Pei XW (2013) Identification and functional analysis of flowering related microRNAs in common wild rice (Oryza rufipogon Griff.). PLoS One. 8:882-844.

Cruz JL, Alves AA, Lecain DR, Ellis DD, Morgan JA (2014) Effect of elevated $\mathrm{CO}_{2}$ concentration and nitrate: ammonium ratios on gas exchange and growth of cassava (Manihot esculenta Crantz). Plant Soil. 374:33-43.

Cvikrová M, Gemperlová L, Dobrá J, Martincová O, Prásil IT, Gubis J, Vanková R (2012) Effect of heat stress on polyamine metabolism in proline-over-producing tobacco plants. Plant Sci. 182:49-58.

Degiovanni BV, Martínez CPR, Motta FO (2010) Producción eco-eficiente de arroz en América Latina. Centro Internacional de Agricultura Tropical (CIAT). Calí, Colombia. Tomo I. pp: 1-25.

Elliott WH (1953) Isolation of glutamine synthetase and glutamotransferase from green peas. The J Biol Chem. 201:661-672.

Ghanbari F, Sayyari M (2018) Controlled drought stress affects the chilling-hardening capacity of tomato seedlings as indicated by changes in phenol metabolisms, antioxidant enzymes activity, osmolytes concentration and abscisic acid accumulation. Sci Hortic. 229:167-174.

Gojon A, Krouk G, Perrine-Walker F, Laugier E (2011) Nitrate transceptor(s) in plants. J Exp Bot. 62:2299-2308.

Gomes-Júnior RA, Moldes CA, Delite FS, Pompeu GB, Gratão PL, Mazzafera P, Lea PJ, Azevedo RA (2006) Antioxidant metabolism of coffee cell suspension cultures in response to cadmium. Chemosphere. 65:1330-1337.

Gratão PL, Monteiro CC, Antunes AM, Peres LEP, Azevedo RA (2008) Acquired tolerance of tomato (Lycopersicon esculentum cv. Micro-Tom) plants to cadmium induced stress. Ann Appl Biol. 153:321-333.

Guo SW, Chen G, Zhou Y, Shen QR (2007a) Ammonium nutrition increases photosynthesis rate under water stress at early development stage of rice (Oryza sativa L.). Plant Soil. 296:115-124.

Guo S, Zhou Y, Shen Q, Zhang F (2007b) Effect of ammonium and nitrate nutrition on some physiological processes in higher plants growth, photosynthesis, photorespiration, and water relations. Plant Biology. 9:21-29. 
Hayat S, Hayat Q, Alyemeni MN, Wani AS, Pichtel J, Ahmad A (2012) Role of proline under changing environments: a review. Plant Signal Behav. 7:1456-1466.

Hessini K, Cruz C, Gandour M, Soltani A, Abdelly C (2009) Do reactive oxygen species (ROS) induced by $\mathrm{NaCl}$ contribute to ammonium accumulation in Spartina alterniflora? J Plant Nutr Soil Sci. 172:851-860.

Hoagland D, Arnon DI (1950) The water-culture method for growing plants without soil. Berkeley: California Agricultural Experiment Station. 347:1-32.

Hoque MA, Banu MNA, Okuma E, Amako K, Akamura $Y$, Shimoishi Y, Murata $Y$ (2007) Exogenous proline and glycinebetaine increase $\mathrm{NaCl}$-induced ascorbateglutathione cycle enzyme activities, and proline improves salt tolerance more than glycine betaine in tobacco Bright Yellow-2 suspension cultured cells. J Plant Physiol. 164:1457-1468.

Jampeetong A, Brix H (2009) Nitrogen nutrition of Salvinia natans effects of inorganic nitrogen form on growth, morphology, nitrate reductase activity and uptake kinetics of ammonium and nitrate. Aquat Bot. 90:67-73.

Kant S, Bi YM, Rothstein SJ (2011) Understanding plant response to nitrogen limitation for the improvement of crop nitrogen use efficiency. J Exp Bot. 62:1499-1509.

Konnerup D, Brix H (2010) Nitrogen nutrition of Canna indicia: Effects of ammonium versus nitrate on growth, biomass allocation, photosynthesis, and nitrate reeducates activity and $\mathrm{N}$ uptake rates. Aquat Bot. 92:142-148.

Li Y, Gao YX, Ding L, Shen QR, Guo SW (2009) Ammonium enhances the tolerance of rice seedlings (Oryza sativa L.) to drought condition. Agr Water Manage. 96:1746-1750.

Lima JE, Kojima S, Takahashi H, von Wirén N (2010) Ammonium triggers lateral root branching in Arabidopsis in an AMMONIUM TRANSPORTER1; 3-dependent manner. Plant Cell. 22:3621-3633.

Liu PW, Liu LH, Remans T, Tester M, Forde BG (2006) Evidence that L-glutamate can act as an exogenous signal to modulate root growth and branching in Arabidopsis thaliana. Plant Cell Physiol. 47: 1045-1057.

Liu $H$, Zhang YH, Yin H, Wang WX, Zhao XM, Du YG (2013) Alginate oligosaccharides enhanced Triticum setivum $\mathrm{L}$. tolerance to drought stress. Plant Physiol Bioch. 62:33-40.

Liu G, Du Q, Li J (2017) Interactive effects of nitrateammonium ratios and temperatures on growth, photosynthesis, and nitrogen metabolism of tomato seedlings. Sci Hortic. 214:41-50.

Loqué D, von Wirén N (2004) Regulatory levels for the transport of ammonium in plant roots. J Exp Bot. 55:12931305.

Luo J, Li H, Liu T, Polle A, Peng C, Luo ZB (2013) Nitrogen metabolism of two contrasting poplar species during acclimation to limiting nitrogen availability. J Exp Bot. 64:4207-4224.

Ma J, LV C, Xu M, Chen G, LV C, Gao Z (2016a) Photosynthesis performance, antioxidant enzymes, and ultrastructural analyses of rice seedlings under chromium stress. Environ Sci Pollut R. 23:1768-1778.
Ma Q, Cao X, Wu L, Mi W, Feng Y (2016b) Light intensity affects the uptake and metabolism of glycine by pakchoi (Brassica chinensis L.). Sci Rep. 6:21200.

Malavolta E, Vitti GC, Oliveira SA de (1997) Avaliação do estado nutricional das plantas: princípios e aplicações. 2ed. Piracicaba: POTAFOS, 319p.

Marschner H (2012) Mineral nutrition of higher plants. 3ed London: Elsevier. 643p

Matsuno H, Uritani I (1972) Physiological behavior of peroxidases isoenzymes in sweet potato root tissue injured by cutting or with black rot. Plant Cell Physiol. 13:1091-1101.

Mihaljević S, Radić S, Bauer N, Garić R, Mihaljević B, Horvat G, Leljak-Levanić D, Jelaska S (2011) Ammonium-related metabolic changes affect somatic embryogenesis in pumpkin (Cucurbita pepo L.). J Plant Physiol. 168:19431951.

Misra N, Gupta AK (2006) Effect of salinity and different nitrogen sources on the activity of antioxidant enzymes and indole alkaloid content in Catharanthus roseus seedlings. J Plant Physiol. 163:11-18.

Mulder EG, Boxma R, van Venn WL (1959) The effect of molybdenum and nitrogen deficiencies on nitrate reduction in plant tissue. Plant Soil. 10:335-355.

Nogueirol RC, Monteiro FA, Gratão PL, Silva BKA, Azevedo RA (2016) Cadmium application in tomato: nutritional imbalance and oxidative stress. Water Air Soil Poll. 227:210.

Piwpuan N, Zhai X, Brix H (2013) Nitrogen nutrition of Cyperus laevigatus and Phormium tenax: Effects of ammonium versus nitrate on growth, nitrate reductase activity and $\mathrm{N}$ uptake kinetics. Aquat Bot. 106:42-51.

Rendón MY, Salva TJG, Bragagnolo N (2013) Impact of chemical changes on the sensory characteristics of coffee beans during storage. Food Chem. 147:279-286.

SAS Institute (2004) SAS/STAT Statistical Analysis System Manual (V. 9.0). SAS Institute, Cary, NC.

Schortemeyer M, Stamp P, Feil B (1997) Ammonium tolerance and carbohydrate status in maize cultivars. Ann Bot. 79:25-30.

Tedesco MJ, Volkweiss SJ, Bohnen H (1985) Análise de solo, planta e outros materiais. Porto Alegre: Departamento de Solos, UFRGS. $188 \mathrm{p}$.

Teh C, Noor SA, Ho C, Mahmood M (2016) Exogenous proline significantly affects the plant growth and nitrogen assimilation enzymes activities in rice (Oryza sativa) under salt stress. Acta Physiol Plant. 38:151.

Xu G, Fan X, Miller AJ (2012) Plant nitrogen assimilation and use efficiency. Annu Rev Plant Biol. 63:153-82.

Yang Y, Zhang Y, Wei X, You J, Wang W, Lu J, Shi R (2011) Comparative antioxidative responses and proline metabolism in two wheat cultivars under short term lead stress. Ecotox Environ Safe. 74:733-740.

Zhang H, Forde BG (2000) Regulation of Arabidopsis root development by nitrate availability. J Exp Bot. 51:51-59. 